\title{
Science Process Skills in Learning Physics: Is there an influence on learning outcomes?
}

\author{
Eka Nurulia ${ }^{1 *}$, Widodo $^{2}$ \\ 1,2 Program Pascasarjan Pendidikan Fisika, Universitas Ahmad Dahlan, Indonesia \\ *Korespondensi: ekanurulia@gmail.com
}

\begin{tabular}{|c|c|}
\hline Info Artikel & \multirow{6}{*}{$\begin{array}{l}\text { Abstract } \\
\text { Student science process skills are very important to support student } \\
\text { learning. In this study aims to provide information about the effect of } \\
\text { science process skills in learning on student learning outcomes. It the } \\
\text { study was conducted at Senior High School } 1 \text { Toboali using Pre- } \\
\text { Experimental Designs with Intact-Group Comparision designs. This study } \\
\text { uses material taught in school, namely the topic of effort and energy. The } \\
\text { data collection technique using the instrument science process skills and } \\
\text { achievement test by dividing the class into two: a control class and } \\
\text { experimental class. The data analyzed in descriptive and inferential (Test- } \\
\text { T). It analyzes showed that the science process skills have some impact } \\
\text { on learning outcomes at a significance level of } 0.00<0.05 \text {. Therefore, it is } \\
\text { important for teachers to apply the science process skills approach to } \\
\text { lengthen student activities during the learning process }\end{array}$} \\
\hline $\begin{array}{l}\text { Accepted } 29 \\
\text { Agustus } 2020\end{array}$ & \\
\hline $\begin{array}{c}\text { Revised } 18 \\
\text { September } 2020\end{array}$ & \\
\hline $\begin{array}{l}\text { Published } 13 \\
\text { January } 2021\end{array}$ & \\
\hline $\begin{array}{c}\text { Keywords: } \\
\text { Student science } \\
\text { process skills; } \\
\text { learning outcomes; } \\
\text { impact learning } \\
\text { physics }\end{array}$ & \\
\hline $\begin{array}{c}\text { (c) } 2020 \text { Universitas } \\
\text { Muhammadiyah } \\
\text { Buton } \\
\text { Under the license } \\
\text { CC BY-SA 4.0 } \\
\text { (c) OC O) }\end{array}$ & \\
\hline
\end{tabular}

\section{Introduction}

Physics is a natural science that studies a natural event that we often encounter in everyday life (Kawuri, et al. 2019) According to Yance (2013), physics is a branch of science that plays a significant role in life, especially in the fields of science and technology. Contextually, physics learning has a vital role in everyday life (Khairunnisa et al. 2020). Based on the 2013 curriculum learning, which is learning that requires students to be more active and skilled in every learning activity (Kawuri \& Fayanto, 2020).

Involving students in the learning process is very important, especially for constructing knowledge, investigating problems, processing and finding solutions, 
one of which is science learning (Siswono, 2017). Learning science is essentially a collection of knowledge, thinking strategies, and procedures for investigation (Collete \& Chiappetta, 1994). Science learning has the perception that science is a product, science is an attitude, and science is a process. This applies to all learning fields of science, among others, Physics, Biology, and Chemistry.

Especially in physics learning, the interaction between teachers and students is significant to build communication between the lessons given and the students' existing understanding (Hunaidah et al. 2019). This is very important because the interaction of students in the classroom occurs in a series of reciprocal relationships between teachers and students in implementing the learning process to achieve specific goals (Fayanto et al. 2019). This interaction or mutual relationship between teachers and students is the main requirement for the learning process to take place. In reality, we see in schools, the learning process in the classroom is not sufficient because teachers are often too active and more dominant in the learning process, while students are made passive. Teachers as educators should not dominate activities, but help create conducive conditions and provide motivation and guidance so that students can develop their potential and creativity, through teaching and learning interactions (Ningsih et al. 2018).

However, the facts say differently, from the results of observations in one school (Senior High School 1 Toboali), it was found that there were still many students who were less active during the learning process. As long as the learning process is only based on a cognitive function, students are only required to memorize without knowing how to carry out the procedures. Also, the teacher provides lessons with monotonous methods such as conventional methods. This is similar to the findings reported by Elvanisi et al. (2018) that almost $80 \%$ of schools do not measure students' science process skills correctly. The teacher only focuses on the cognitive assessment of students. The same thing is supported by Nisa's (2014) study that another finding obtained in learning physics in class is that if discussion activities are held, there is no productive question and answer which leads to concept collection, students tend to be passive and not interested in learning activities.

Besides, the learning that is carried out applies experimental activities even though with significantly less frequency and the ability of students in problem formulation, formulating hypotheses, determining variables, and making graphs and analyzing them is not taught in-depth so that knowledge in conducting experiments is very lacking. If this happens, then after the end of learning, students tend to lose the essence of what has been conveyed because it is considered less impressive. The element expected in education is that students understand the concepts taught during the learning process and apply them in daily life. Because the teaching received by students is less impressive, of course, it also has an impact on the poor learning outcomes of students. This argument is in line with the results of an interview conducted on one of the physics subject teachers who said that so far, the learning process is more dominant in one direction. Where students only focus more on memorizing the material. Of course, this is not in line with the government's expectations for facing the 21st century. Therefore, a solution/alternative is needed to overcome this.

Thus, the author offers one way, namely by applying science process skills. This is because to train the physics skills of an individual is to use science process 
skills in learning. Science Process Skills are essential for every individual as a primary asset for someone to solve their life problems in everyday life (Dahar, 1996). KPS melibatkan keterampilan intelektual, manual, dan sosial yang digunakan untuk membangun pemahaman terhadap suatu konsep atau pengetahuan dan meyakinkan atau menyempurnakan pemahaman yang sudah terbentuk (Susilowati, 2019).

So that students who have these skills can find a new concept, principle or theory as a development of an existing idea or to refute a discovery. Sari et al. (2017) reported that process skills involve cognitive and intellectual skills. Mental and academic skills are concerned because it consists of the process skills of students using their minds. Awalliyah et al. (2015) wrote that performance skills contain aspects of cognitive skills, intellectual skills that are the background for mastery of science process skills and sensorimotor skills.

Markawi (2013) reports that the use of science process skills in learning can improve students' reasoning and problem-solving abilities. Meanwhile, Sinuraya et al. (2019) reported that science process skills and creativity influenced $47.20 \%$ of learning outcomes. Therefore, the authors are interested in examining whether there is an effect of science process skills on students' learning outcomes, especially at Senior High School 1 Toboali. The study is expected to provide information about the role of science process skills in improving physics learning outcomes. Also, this study is a preliminary study conducted by researchers to support the development of thesis research currently being developed by the researcher.

\section{Method}

\subsection{Research models}

The type of research used is the quantitative method of Pre-Experimental Designs with the Intact-Group Comparision design, namely variable study by dividing two groups, namely the experimental group (which is treated) using the project-based learning model and the control group (which is not treated) using the method conventional.

\subsection{Research subjct}

This research was conducted at Senior High School 1 Toboali Bangka Selatan in the $2019 / 2020$ school year. The population in this study was class $X$ which consisted of one class and the sample in this study was one class, namely class X MIPA 4, totalling 36 students who were divided into two groups, namely the experimental group and the control group.

\subsection{Data collection technique}

The data collection technique used the science process skills observation sheet. Besides, test techniques are also used to see the results of studying physics.

\subsection{Data analysis technique}

Science process skills data in the form of scores were obtained from observations made by two observers during the learning process. Science process skills studied consisted of 4 indicators of science process skills, namely formulating 
hypotheses, observing, conducting experiments and communication. Calculation of students' science process skills is done by tabulating the data so that the percentage of each sub-variable can be calculated using the formula (Purwanto, 2013):

$$
N_{P}=\frac{R}{S_{M}} \times 100 \%
$$

The data analysis technique used to test the effect of science process skills on learning outcomes uses the t-test with the help of SPSS 23.0, but before testing the hypothesis, first, perform the normality test and data homogeneity test to see the data is typically distributed and homogeneous. And to determine the increase in science process skills of the experimental and control groups, a test was carried out using the N-Gain equation, namely

$$
\langle g\rangle=\frac{T_{\text {posttest }}-T_{\text {pretest }}}{T_{\text {maks }}-T_{\text {pretest }}}
$$

\subsection{Research hypotesis}

The research hypotheses built in this study are:

$\mathrm{H}_{0}$ : there is no effect of science process skills on physics learning outcomes at Senior High School 1 Toboali

$\mathrm{H}_{\mathrm{a}}$ : there is an effect of science process skills on physics learning outcomes at Senior High School 1 Toboali

\section{Result and Discussion}

Based on the results of research in class X MIPA 4 SMA N 1 Toboali obtained data from observation sheets of science process skills assessment conducted by two observers during learning activities and indicators assessed from science process skills consisting of 4 arrows, namely formulating hypotheses, observing, conducting experiments and communication. Research data can be seen in Figure 1.

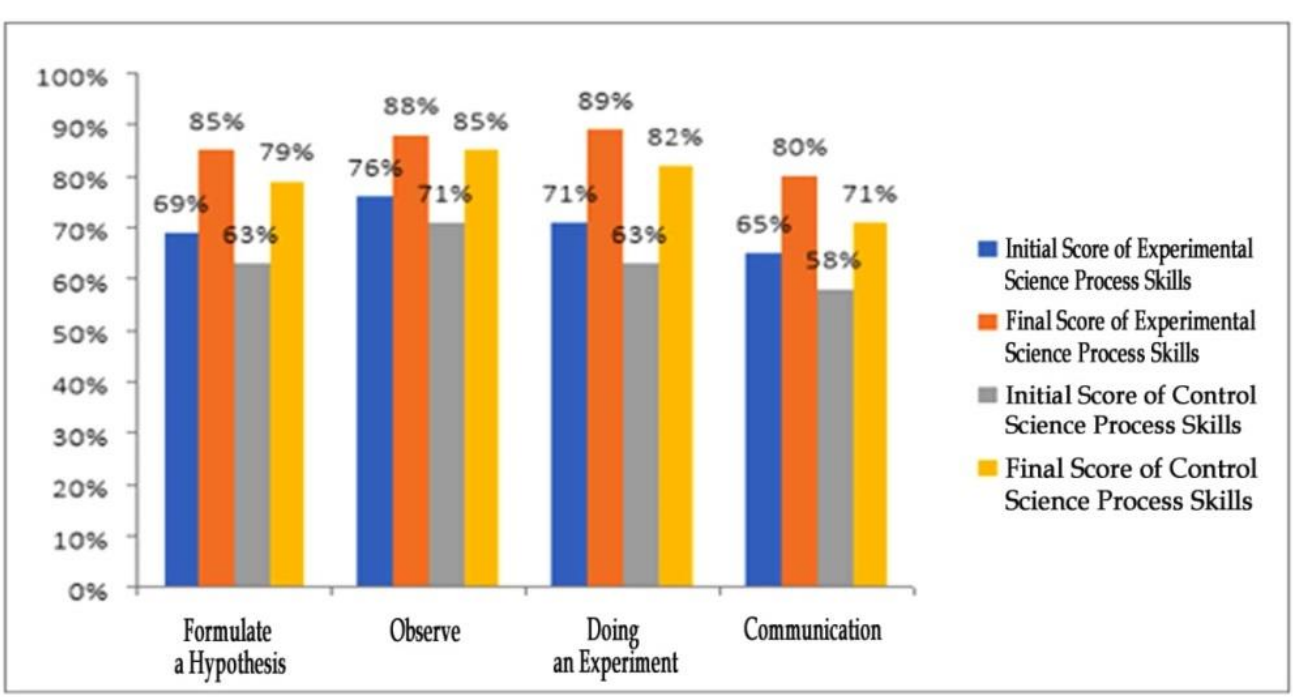

Figure 1. Graph of Science Process Skills Improvement on student learning outcomes 
Based on Figure 1, it can be seen that the data on science process skills in the experimental group and the control group has increased in each indicator. From the data, in Figure 1, the average science process skills of the experimental group were $78 \%$ while the control group was $71 \%$. The results of improving science process skills can also be shown in Figure 2

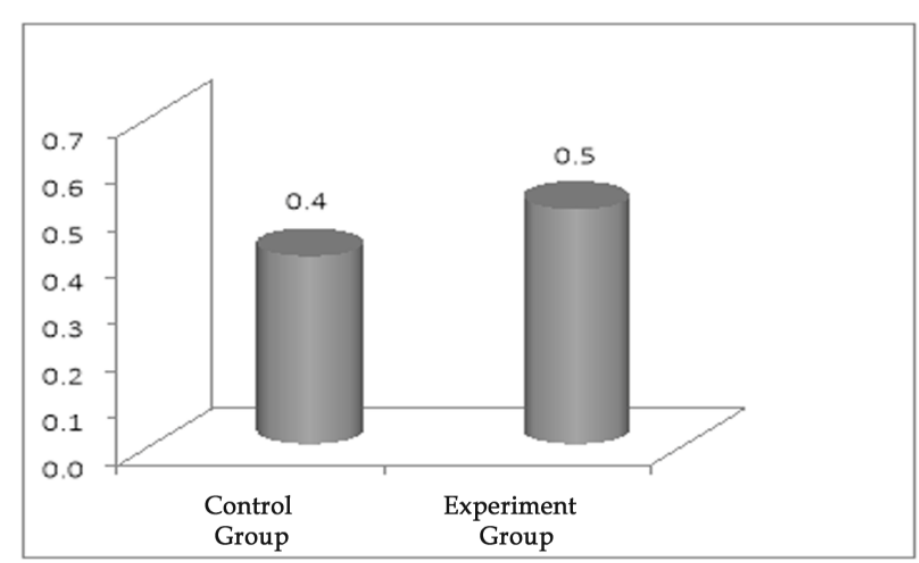

Figure 2. Graph of the average value of student science processing skills $\mathrm{N}$-gain improvement on learning outcomes

Figure 2, the results obtained for the science process skills of the experimental and control groups 0.5 and 0.4 , respectively, with the moderate category. From these results, it can be said that there is an increase in science process skills in both the experimental group and the control group. Following are the results of the normality test data can be seen in Table 1.

Table 1. Results of the calculation of the normality test

\begin{tabular}{ccc}
\hline No & \multicolumn{1}{c}{ Data Name } & Sig. \\
\hline $\mathbf{1}$ & Initial Score KPS Control & 0,252 \\
$\mathbf{2}$ & Final Score KPS Control & 0,481 \\
$\mathbf{3}$ & Initial KPS Experiment Score & 0,151 \\
$\mathbf{4}$ & Final KPS Experiment Score & 0,600 \\
\hline
\end{tabular}

Based on Table 1, the results of the initial and final scores of the control group were 0,252 and 0,481 , while the initial and final scores of the experimental group were 0,151 and 0,600 . Based on these results, it can be said that the science process skills data is usually distributed because the significance value obtained is more significant than 0,05 . The results of the homogeneity test can be seen in Table 2.

Table 2. The results of the calculation of the homogeneity test

\begin{tabular}{ccc}
\hline No & Data Name & Sig. \\
\hline 1 & Science Process Skills & 0,426 \\
\hline
\end{tabular}

Based on the data in Table 2, the significant value of the homogeneity test for students' science process skills was 0,426 . Based on the significance value (sig) obtained is more significant than 0.05 , it can be concluded that the variance of science process skills is homogeneous. The results of hypothesis testing to see the effect of project-based learning models on improving science process skills using the paired sample test can be seen in Table 3 . 
Table 3.The results of the Paired Samples Test calculation

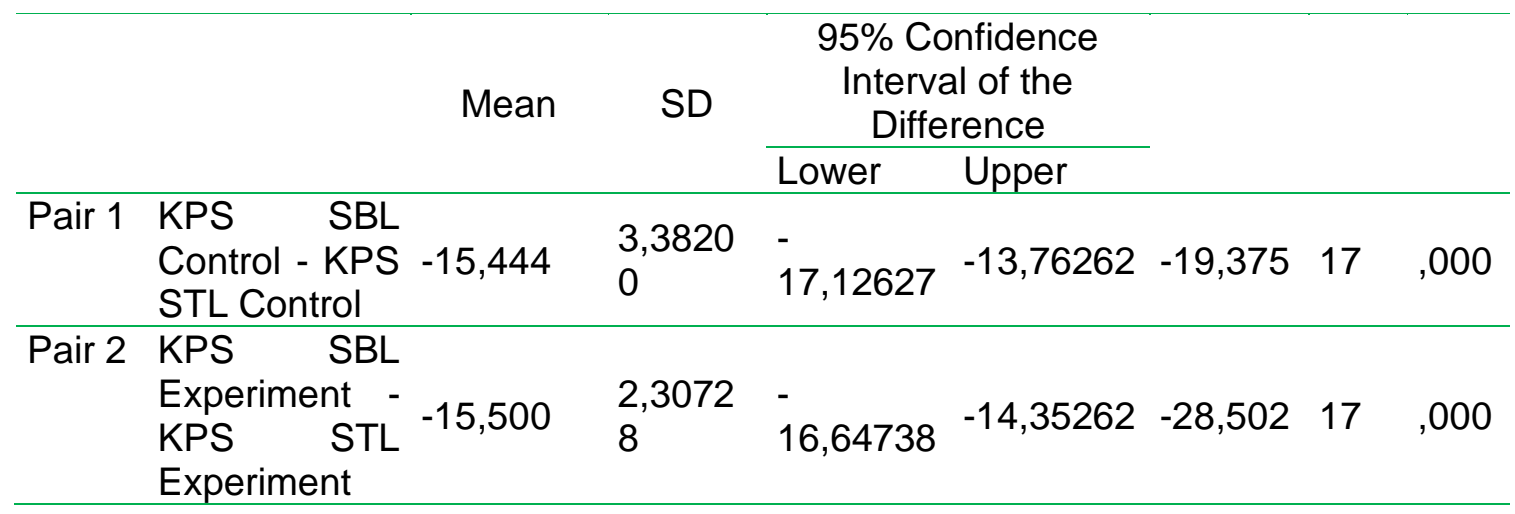

Based on the paired sample T-Test output table above using a significance level of $5 \%$ tau 0,05 , for science process skills the value at significance (2-tailed) $0.000<0,05$ is rejected, and it can be said that there is an effect of science process skills students on student learning outcomes.

The application of student science process skills can affect student learning outcomes, and this can be seen in Figure 1. The role of science process skills is constructive during the learning process. This is because science process skills are an approach to teaching natural science based on observations of what a scientist is doing (Lestari \& Diana, 2018). This can be seen in Figure 1, where the indicators between the experimental class and the control class have different results.

This is because in the control class the application of Science Process skills (KPS) includes the following activities: (1) observing, namely the skills to collect data or information through the application of the senses based on the activities carried out (Ambarsari, 2012); (2) interpreting, namely the skills to analogize an experiment with existing concepts (Verawati et al. 2014); (3) discussing, namely skills to be able to work together in teams to discuss problems (Oktaviani, 2017(4) analyzing, namely the ability to be able to diagnose issues based on the observation skills that have been carried out; (5) concluding the results of the research, namely the skills to finish a series of activities that have been carried out after analysis and discussion; (6) applying, namely applying learning outcomes in the form of information, conclusions, concepts, laws, theories, and skills; (6) applying, namely applying learning outcomes in the form of (7) communicating, namely conveying the acquisition or learning outcomes to others in the way of writing, pictures, motion, action, or appearance. Which, of course, has a different impact between the experimental class and the control class (Reviandari, 2008; Sari, 2016. This also affects the learning outcomes of students.

Visible differences in student learning outcomes from the $\mathrm{N}$-gain test produced and the results of hypothesis testing. However, the results of the $\mathrm{N}$-gain test did not have a significant impact. However, science process skills still influence learning outcomes. The same thing was found from the results of the analysis of the hypothesis test that there was an effect of science process skills on student learning outcomes with the resulting significance level being 0.00 less than 0,05. Nasir et al. (2019) described that the science process skills-based project-based learning could improve the cognitive achievement of students with a significance level of 0.013 . Another study reported that the use of science process skills could improve learning outcomes, with a percentage of $94.74 \%$ (Damopolii et al. 2018). 
Meanwhile, Janah et al. (2018) informed that there is a relationship between science process skills and learning outcomes in problem-based learning model learning gained by $31.82 \%$. Similar results study conducted by Hadija et al. (2019) who reported that there was an effect of practicum application on science process skills and student learning outcomes. Therefore, of course, science process skills contribute to the success of students during the learning process.

\section{Conclusions}

Based on the results obtained, it can be concluded that there is an effect of students' science process skills on student learning outcomes on topic work and energy in class X MIPA 4 at Senior High School 1 Toboali. This study is a preliminary thesis development study which will then be implemented into a further evaluation stage with a vast scope.

\section{References}

Ambarsari, W. (2012). Penerapan pembelajaran inkuiri terbimbing terhadap keterampilan proses sains dasar pada pelajaran biologi siswa kelas VIII SMP Negeri 7 Surakarta.

Awalliyah, S., Siahaan, P., Nugraha, M. G., \& Kirana, K. H. (2015). Hubungan Keterampilan Proses Sains dengan Penguasaan Konsep Serta Kaitannya Dengan Gaya Kognitif Field Dependent-Field Independent. Jurnal Pengajaran MIPA, 20(2), 181-185.

Collette, A. T., \& Chiappetta, E. L. (1984). Science Instruction in the Middle and Secondary Schools. The CV Mosby Company, 11830 Westline Industrial Drive, St. Louis, MO 63146.

Dahar, R.W. (1989). Teori-Teori Belajar. Jakarta: Erlangga

Damopolii, I., Yohanita, A. M., Nurhidaya, N., \& Murtijani, M. (2018). Meningkatkan keterampilan proses sains dan hasil belajar siswa melalui pembelajaran berbasis inkuiri. Jurnal Bioedukatika, 6(1), 22-30.

Elvanisi, A., Hidayat, S., \& Fadillah, E. N. (2018). Analisis Keterampilan Proses Sains Siswa Sekolah Menengah Atas. Jurnal Inovasi Pendidikan IPA, 4(2), 245-252.

Fayanto, S., Musria, M., Erniwati, E., Sukariasih, L., \& Hunaidah, H. (2019). Implementation of quantum teaching model on improving physics learning outcomes in the cognitive domain at junior high school. IJIS Edu: Indonesian Journal of Integrated Science Education, 1(2), 131-138.

Hadija, H., Anas, M., \& Tahang, L. Penerapan Metode Praktikum untuk Meningkatkan Keterampilan Proses Sains Dan Hasil Belajar IPA Fisika Peserta Didik Pada Materi Pokok Getaran dan Gelombang Kelas VIII SMP Negeri 2 Bungku Selatan. Jurnal Penelitian Pendidikan Fisika, 5(1), 19-27.

Hunaidah, M., Armin, A., \& Fayanto, S. (2018, May). Penerapan Model Pembelajaran Predict-Observe-Explain (POE) Dengan Metode Demonstrasi Untuk Meningkatkan Aktivitas Dan Hasil Belajar IPA Fisika Materi Pokok Kalor Kelas VII2 SMP Negeri 15 Kendari. In Quantum: Seminar Nasional Fisika, dan Pendidikan Fisika (pp. 293-298). 
Janah, M. C., Widodo, A. T., \& Kasmui, K. (2018). Pengaruh model problem based learning terhadap hasil belajar dan keterampilan proses sains. Jurnal Inovasi Pendidikan Kimia, 12(1).

Kawuri, M. Y. R. T., Ishafit, I., \& Fayanto, S. (2019). Efforts to improve the learning activity and learning outcomes of physics students with using a problembased learning model. IJIS Edu: Indonesian Journal of Integrated Science Education, 1(2), 105-114.

Kawuri, M. Y. R. T., \& Fayanto, S. (2020). Penerapan Model Discovery Learning Terhadap Keaktifan dan Hasil Belajar Siswa Kelas X MIPA SMAN 1 Piyungan Yogyakarta. Jurnal Penelitian Pendidikan Fisika, 5(1), 1-8.

Khairunnisa, K., Ishafit, I., \& Fayanto, S. (2020). Physics Teaching: Development of Lectora Inspire with Multiple-Representation Approach to Reduce Of Misconception. Jurnal Dedikasi Pendidikan, 4(2), 159-170.

Lestari, M. Y., \& Diana, N. (2018). Keterampilan Proses Sains (KPS) Pada Pelaksanaan Praktikum Fisika Dasar I. Indonesian Journal of Science and Mathematics Education, 1(1), 49-54.

Markawi, N. (2015). Pengaruh Keterampilan Proses Sains, Penalaran, Dan Pemecahan Masalah Terhadap Hasil Belajar Fisika. Formatif: Jurnal IImiah Pendidikan MIPA, 3(1).

Nasir, M., Fakhrunnisa, R., \& Nastiti, L. R. (2019). The implementation of projectbased learning and guided inquiry to improve science process skills and student cognitive learning outcomes. International Journal of Environmental and Science Education, 14(5), 229-238.

Ningsih, S., Karim, H., \& Nurhayati, B. (2018, November). Pengaruh Penerapan Pendekatan Keterampilan Proses Sains Terhadap Hasil Belajar Biologi Peserta Didik Kelas X SMA Negeri 6 Sinjai. In Seminar Nasional Biologi.

Nisa, C. (2014). Pengaruh Penerapan Pembelajaran Penemuan Terbimbing Dengan Mengintegrasikan Keterampilan Proses Sains Terhadap Hasil Belajar Siswa SMP Negeri 1 Kamal. Inovasi Pendidikan Fisika, 3(1).

Oktafiani, P., Subali, B., \& Edie, S. S. (2017). Pengembangan alat peraga kit optik serbaguna (AP-KOS) untuk meningkatkan keterampilan proses sains. Jurnal Inovasi Pendidikan IPA, 3(2), 189-200.

Purwanto. 2013. Evaluasi Hasil Belajar. Yogyakarta : Pustaka Belajar

Sari, H. K. (2016). Peningkatan Keterampilan Proses Sains dan Hasil Belajar Fisika Siswa pada Model Pembelajaran Kooperatif Tipe Student Team Achievement Division. Tadris: Jurnal Keguruan Dan Ilmu Tarbiyah, 1(1), 1522.

Sari, I. N., Azwar, I., \& Riska, R. (2017). Kontribusi keterampilan proses sains siswa terhadap hasil belajar siswa pada materi wujud zat dan perubahannya. Jurnal Pendidikan Informatika dan Sains, 6(2), 257-266.

Siswono, H. (2017). Analisis Pengaruh Keterampilan Proses Sains Terhadap Penguasaan Konsep Fisika Siswa. Momentum: Physics Education Journal, 83-90. 
Sinuraya, J., Panggabean, D. D., \& Wahyuni, I. Analysis Of Relationship Science Process Skills And Creativity With The Cognitive Learning Outcomes Used Of The Icare Practice Based On Worksheet On Learning High School Physics Courses. Jurnal Pendidikan Fisika, 8(2), 91-96.

Susilowati, S. A. (2019). Penerapan Pendekatan Keterampilan Proses Sains (KPS) Untuk Meningkatkan Pemahaman Konsep Siswa Pada Pembelajaran IPA. Jurnal Elementaria Edukasia, 2(1).

Verawati, N. N. S. V., Prayogi, S., \& Asy'ari, M. (2014). Reviu literatur tentang keterampilan proses sains. Lensa: Jurnal Kependidikan Fisika, 2(1), 194-198.

Widyatiningtyas, Reviandari. 2008. Peranan Guru dalam Melakukan Penilaian Keterampilan Proses. [Online] tersedia: http://educare.fkipunla.net. Data akses: 06/7/2020. 10:00 WITA.

Yance, R. D. (2013). Pengaruh Penerapan Model Project Based Learning (PBL) Terhadap Hasil Belajar Fisika Siswa Kelas XI IPA SMA Negeri 1 Batipuh Kabupaten Tanah Datar. Pillar of Physics Education, 1(1). 